\title{
Fulfilling the Right of Education during Covid- 19 Pandemic Period: A Comparative Study
}

\author{
Hwian Christianto ${ }^{1}$ \\ Michelle Kristina $^{2}$ \\ ${ }^{1}$ Faculty of Law, Universitas Surabaya, Indonesia. E-mail: hw christianto@staff.ubaya.ac.id \\ ${ }^{2}$ Faculty of Law, Universitas Surabaya, Indonesia, Indonesia.
}

\section{Article Info}

\section{Keywords: \\ Right to Education; \\ Criminal Sanction; \\ Covid-19 pandemic. \\ How to cite (APA Citation Style): \\ Christianto, H. \& Kristina, M. (2022). "Fulfilling the Right of Education during Covid-19 Pandemic Period: A Comparative Study". Jambura Law Review. JALREV 4 (1): 1- 17}

\begin{abstract}
The right of education for citizens has been fulfilled diversely following the government policies. This study aimed to emphasize the importance of the education right and the imposition of criminal sanctions in order to protect the right of education during the Covid-19 Pandemic particularly in Indonesia, Japan and Australia. Normative juridical research methods described that government policies as outlined in the legislation constantly followed by criminal sanctions. The concept of education right was understood in a different way during the Covid-19 pandemic, as one of the derogable-right or adapted human right. As result, three countries understanding the right of education as a basic human right even during the pandemic period related to right of education. For its fulfillment, some education right uses criminal sanctions as an ultimum remidium like Indonesia dan Australia or does not impose criminal sanctions at all like Japan.
\end{abstract}




\section{Introduction}

Tedros Adhanom Ghebreyesus, Director-General of World Health Organization (WHO) on March 11, 2020 stated that Covid-19 was considered as a global pandemic $^{1}$. There were 216 countries reporting Covid-19 cases by March 25, 2020 including Indonesia, Japan, and Australia. ${ }^{2}$ Each country carried out various policies for the handling of the Covid-19 pandemic in its territory. Indonesia chose to implement a Large Scale Social Restrictions (PSBB) policy as an effort ${ }^{3}$ to deal with the Covid-19 pandemic. ${ }^{4}$ Japan actually did not enforce any written rules, and the government only advised that the citizens shall avoid crowds, close contact, and closed spaces based on local culture and ethics. ${ }^{5}$ While Australia took on different measure by conducting forced detention or getting rid of residents which infected with the virus and making forced efforts in administering vaccines ${ }^{6}$ The three government policies had similarities in terms of protecting citizens from Covid-19 virus infection which known as the physical distancing, by closing several places which has the potential to raise crowds, including schools.

The Study Form Home policy is implemented by taking into account the situation and condition of the citizens in order to avoid Covid-19 infection. Teaching and learning activities are also carried out through the use of internet to facilitate the delivery of educational materials from teachers to students. This is one of the efforts to prevent the transmission of Covid-19 which can be easily transferred from symptomatic people to other people in close proximity through droplets (water-filled particles) that enter the

1 World Health Oranization. (2020). Coronavirus disease (COVID-19) pandemic. Retrieved from https://www.who.int/emergencies/diseases/novel-coronavirus-

2019? gclid=EAIaIQobChMIs9Xjy4nO6QIVCldgCh19EAjmEAAYASAAEgJRZfD BwE (accessed May 12, 2021)

2 Ibid.

${ }^{3}$ Hamid, A. R. A. H. (2020). "Social responsibility of medical journal: A concern for covid-19 pandemic". Medical Journal of Indonesia. Vol 29 (1): 1-3.

${ }^{4}$ Yunus, N. R., \& Rezki, A. (2020). "Kebijakan Pemberlakuan Lock Down Sebagai Antisipasi Penyebaran Corona Virus Covid-19". Salam: Jurnal Sosial Dan Budaya, Vol 7 (3): 228-229

5 Pranita, E. (2020). Cara Jepang Lawan Corona, Pemimpin Daerah Punya Kebijakan Sendiri Artikel ini teCara Jepang Lawan Corona, Pemimpin Daerah Punya Kebijakan Sendiri. Retrieved from https://www.kompas.com/sains/read/2020/04/18/110000123/cara-jepang-lawan-coronapemimpin-daerah-punya-kebijakan-sendiri?page $=3$ (accessed Maym 12, 2021)

${ }^{6}$ ABC Australia. (2020). Cara Australia Tangani Corona: Dari Larang Jabat Tangan Sampai Penahanan Paksa. Retrieved from : https://news.detik.com/abc-australia/d-4924295/cara-australia-tanganicorona-dari-larang-jabat-tangan-sampai-penahanan-paksa (accessed May 12, 2021) 
mucosa (mouth and nose) and objects touched by symptomatic people. Therefore, it is hoped that the implementation of education will not become a means to spread Covid-19, and the governments prioritize the health and even safety of all parties.

Teaching and learning process was also not allowed to be performed directly, face to face. Thus, learning process also experienced obstacles in terms of facilities and opportunities to gain access to education which should be done remotely. The use of information technology in the form of internet has emerged as the basic need related to education access that not all citizens able to afford it. Gaps within social and economic conditions also the situations faced by each citizen were the main obstacles. As a consequence, students who were constrained in facilities and internet access could not acquire their right for education. These conditions should have been addressed by the government before the implementation of various policies in order to deal with the Covid-19 pandemic.

\section{Problem Statement}

Based on the background of the Covid-19 pandemic policies which limits the space and interaction between citizens, it is interesting to discuss in advance the importance of the right of education for these three countries that underlied the implementation of the government policy in the field of education. Understanding of the concept of education right shall be the basis for deciding whether the use of criminal sanctions is necessary or not for its violators

\section{Methods}

This research used a normative juridical method that emphasized on international legal instruments related to the Right of Education as Human Right such as the Universal Declaration of Human Right 1948 and the International Covenant on Economic, Social and Cultural Right 1966. This instrument was reviewed based on the policies of the government of the Republic of Indonesia, Japan and Australia in terms of education from the Constitution and legislation in the field of Human Right, specifically the right of education. By understanding the regulation of the right of education, later then the paradigm / concept of education carried out by each country could be understood. The education paradigm or concept of each country was then linked to related government policy on dealing with the spread of Covid-19, more 
specifically social distancing regulations. The results of the study as a conclusion were drawn from the synergy of International Instruments related to the Right of Education with national laws and regulations of each country. Commitment to fulfill the right of education was associated with the use of criminal sanctions as an effort to guarantee the fulfillment of the right to education with various policies and strategies

\section{Discussion}

\subsection{Internalization and Externalization of International Instruments}

The struggle to notice the importance of human right in the international world was finally marked by the Universal Declaration of Human Right in Paris on December 10, 1948 (UDHR). ${ }^{7}$ The right of education was regulated on Article 26 paragraph (1) and (2) of UDHR "Everyone has the right to education ..." with the aim of "... to the full development of the human personality and to the strengthening of respect for human right and fundamental freedoms. "8 The primary concept of education right, according to the UDHR, was the basic right within each person to develop themselves based on an understanding of human right and human relationships with others. This means that the right of education had two interests, self-interest and shared interests. The derivative understanding of Article 26 of the UDHR was then described on Article 13 paragraph (1) of the International Covenant on Economic, Social and Cultural Right (ICESCR). The ICESCR, signed on December 16, 1966, affirmed the right of education on 3 articles. Article 13 (1) ICESCR echoed Article 26 paragraph (1) UDHR with the emphasis on "Education shall be directed to the full development of the human personality and the sense of its dignity, and shall strengthen the respect for human right and fundamental freedoms." ${ }^{\prime 9}$

The right of education was not just limited on the knowledge of one's personal skills but it is also fundamental in the development of human personality, dignity, and status without setting aside the respect for human right and basic freedoms of others. If observed further, it's found that the right of education was a part of the right to

\footnotetext{
7 United Nations. (1948). Universal Declaration of Human Right. Retrieved from : https://www.ohchr.org/EN/UDHR/Documents/UDHR Translations/eng.pdf (accessed May 12, 2021)

8 Ibid

9 United Nations. (1966). International Covenant on Economic, Social and Cultural Right. Retrieved from: https://www.ohchr.org/Documents/ProfessionalInterest/cescr.pdf (accessed May 12, 2021)
} 
develop oneself which impacts on personal life as well as social life. This was reflected on the Article 13 paragraph (1) ICESCR which stated that "education shall enable all persons to participate effectively in a free society, promote understanding, tolerance and friendship among all nations and all racial, ethnic or religious groups, and further the activities of the United Nations for the maintenance of peace." (United Nations, 1966) It means that the right of education was the key in understanding human right as an effort to self-awareness of the dignity of human beings as social beings based on tolerance for differences in nationalities, races, ethnicities or religious groups. The emphasis on the importance of the right to education by ICESCR was that a country must carry out education on several levels, such as Primary education, Secondary education, Higher education and Fundamental education (Article 13 ICESCR). Specifically, Primary education must be carried out freely for all (Article 13 paragraph (2) letter b), otherwise, the State can carry out an action plan specifically on this matter (Article 14). Thus, the international instrument asserted the right to education as a basic right of every person to develop himself completely for the sake of oneself and the society. One important thing was the state's responsibility in fulfilling the right of education (Articles 13, 14 and 15 ICESCR). One form of fulfilling the right of education was required by ICESCR, that States shall establish an education system (Article 13 number 2 letter e ICESCR).

\section{Indonesia}

Since Indonesia declared its independence, the right of education has been focused as a part of the country's goal of "educating the people of the nation and participating in carrying out world order based on independence, lasting peace, and social justice". Fulfillment of the right of education was regarded significant for the country. Sujatmoko emphasized that education played a major role in ensuring the survival of the nation because it's related to the quality of human resources. ${ }^{10}$ The goal of this country was further outlined in the Constitution, the 1945 Constitution of the Republic of Indonesia (UUDN RI 1945) specifically in Article 31. The substance of Article 31 of the 1945 Constitution of the Republic of Indonesia consisted of 3

10 Sujatmoko, E. (2010). "Hak Warga Negara Dalam Memperoleh Pendidikan”. Jurnal Konstitusi, Vol 7 (1): 184-188. 
important things. First, the recognition of the right of education as a human right is protected by the constitution. Article 31 paragraph (1) of the 1945 Constitution of the Republic of Indonesia was clearly in line with Article 26 paragraph (1) of the UDHR and Article 13 paragraph (1) of ICESCR. Arising juridical implications, was that the right of education became the commitment of the state to guarantee its fulfillment. The right of education was also recognized by Article 28C paragraph (1) of the UUDNRI as the right to develop oneself and benefit from science and technology. Second, the citizens are obliged to attend basic education. This provision also had the same goal with Article 26 paragraph (2) UDHR and Article 13 number 2 letter (a) ICESCR. Recognition of the right of education was inseparable from the role of citizens and the direction of the Government to take part in free basic education by giving education funding from the Government. The State must even prioritize the education budget of at least $20 \%$ of the State/Regional Budget (Article 31 paragraph (4) of the 1945 Constitution of the Republic of Indonesia). Third, the State must create a national education system for all levels with the aim of increasing faith, piety, noble character, and science and technology based on religious values and national unity.

The importance of fulfilling the right of education also continues in Law Number 20 of 2003 on the National Education System (UU Sisdiknas). Education was underlined as "a conscious and planned effort to create a learning atmosphere and learning process so that students actively develop their potential ..." (Article 1 number 1 of UU Sisdiknas), in other words, education is a process! The learning process that involves educational staff and students together so that students actively develop themselves. If observed carefully, it is clear that education is the main and important thing for the development of Indonesia's current and future human resources. ${ }^{11}$ Even the National Education System Law has introduced 3 types of education that citizens could take, such as formal education through formal educational institutions with formal education standards from the government, non-formal education through trainings of non-formal skills to support self-development, and informal education that applies in

\footnotetext{
${ }^{11}$ Christianto, Hwian. (2020). "Penggunaan Media Internet dalam Pemenuhan Hak atas Pendidikan di Masa Pandemi Covid-19: Perspektif Hak Asasi Manusia dan Hukum Pidana”. Jurnal HAM. Vol.11(2): 241
} 
families and communities (Chapter VI of the National Education System Law). Challenges arrived when a process of conscious and planned learning had to deal with the Covid-19 pandemic situation.

The policy of the Government of the Republic of Indonesia in fulfilling the rights to education during the Covid-19 pandemic is clearly visible through the Presidential Decree of the Republic of Indonesia Number 11 of 2020 concerning the Establishment of a Covid19 Public Health Emergency and Government Regulation Number 21 of 2020 concerning Large-Scale Social Restrictions (PSBB) in the context of accelerating the handling of Covid-19. The two legal provisions not only confirm the existence of a health emergency but also stipulate for the suspension of school activities in accordance with Article 59 paragraph (3) of Law Number 6 of 2018 concerning Health Quarantine. However, the Government of the Republic of Indonesia set a different policy, studying from home (study form home), instead of school holidays. This policy shows the attention of the government of the Republic of Indonesia on the importance of the learning process to continue even during the Covid-19 pandemic. The Ministry of Education and Culture of the Republic of Indonesia also supports the implementation of online education that can be carried out optimally, one of which is through the Smart Indonesia Program (PIP) in accordance with the Regulation of the Minister of Education and Culture of the Republic of Indonesia Number 10 of 2020, providing subsidies of 9 trillion rupiah given to students, teachers, and lecturers in Indonesia to facilitate the implementation of online learning. This policy is also stated in the Regulation of the Minister of Education and Culture Number 32 of 2020 \& Regulation of the Minister of Education and Culture of the Republic of Indonesia Number 44 of 2020 concerning General Guidelines for the Distribution of Government Assistance at the Ministry of Education and Culture. Moreover, the Ministry of Education and Culture of the Republic of Indonesia also released Indonesia Cyber Education (ICE) provides the SPADA application to assist distance learning through the Massive Open Online Source (MOOC) learning system. This policy addresses the gap in economic and social conditions faced by the community so that the fulfillment of the rights to education during the pandemic can be guaranteed.

Japan

Japan also views education as an important matter for citizens as affirmed in 
The Constitution of Japan as enacted on May 3, 1947 (CoJ 1947) and outlined in Act No. 120 of December 22, 2006 as Fundamental Law of Education (FLE 2006). The second paragraph of CoJ 1947 emphasized "We, the Japanese people, the desire for peace for all time and are deeply conscious of the high ideals controlling human relationships, and we have determined to preserve our security and existence."12 Japan affirmed the right of education as a part of efforts to shape world peace through relationships and maintain security and existence through self-development. Furthermore, recognition of the right of education was regulated in Article 13, Article 23, and Article 26 of CoJ 1947. Article 13 emphasizes "All of the people shall be respected as individuals. Their right to live, freedom, and the pursuit of happiness shall, to the extent that it does not interfere with the public welfare, be the supreme consideration in legislation and in other governmental affairs. "Human right principles that applied and were recognized in Japan are understood as right inherent in each individual person. The right to live, the right of independence, and the right of prosperity will always be acknowledged as long as they do not conflict with public interests, laws, and regulations.

Based on this regulation, human rights were recognized as rights protected by the Japanese constitution. More specifically, the right of education was guaranteed in an atmosphere of academic freedom (Article 23 CoJ 1947). Japan did not merely recognize science and technology but also freedom to create and improvise existing science and technology. This is a different area of emphasis in the goal of independent education. The purpose of "academic freedom" was explained by Article 2 FLE $2006^{13}$ on two main points, first, the students themselves in terms of ability, culture, and selfautonomy for their work, and second, fostering human values, the value of life and environmental preservation, and the value of tradition and culture towards peace and the international community. The latter was very unique when education was based on the value of Japanese traditions and culture. Yasumasa explained that education,

12 Prime Minister of Japan and His Cabinet. (1946). The Constitution of Japan. Retrieved from:https://japan.kantei.go.jp/constitution_and_government_of_japan/constitution_e.html (Accessed May 12, 2021)

13 Prime Minister of Japan and His Cabinet (2006). Basic Act on Educatioin Japan. Retrieved from:https://www.mext.go.jp/en/policy/education/lawandplan/title01/detail01/1373798.htm (Accessed May 12, 2021) 
especially in Japan, was related to moral education (Shushin) and disciplinary education (Shitsuke). ${ }^{14}$ Education priorities in Japan were aimed at moral education (Shushin) and self-discipline (Shitsuke) which continue to be maintained in the Japanese education reform program known as "Rainbow Plan". ${ }^{15}$ Both of these educations are the priorities for Japanese society both formally and informally. ${ }^{16}$ Therefore, it is no surprise that education in Japan was based on the value of tradition and culture. The focus on fulfilling the right of education was regulated in Article 26 of CoJ 1947 which stated that the right to education is guaranteed to be able to receive equal education according to his ability. Education is indeed given to citizens, but the fulfillment still pays attention to the abilities of students themselves.

Further elaboration on CoJ 1947 regarding the right of education found in the Preamble Section confirmed that education has an important contribution to "the democratic and cultural state we have built through wireless efforts, also hope to contribute to world peace and to improve the welfare of humanity." ${ }^{17}$ Furthermore, it is emphasized that "education values the dignity of the individual, that endeavors to cultivate a people rich in humanity and creativity who long for truth and justice and who honor the public spirit, that passes on traditions, and that aims to create a new culture". The statement showed that education regulations supported the fulfillment of the right of education based on Japanese morality "fully developing the individual character" (Article 1 FLE 2006). As an effort to fulfill the right of education, Article 4 of FLE 2006 emphasized the obligation of the central government and local governments to provide equal opportunities in order to receive education according to their ability without discrimination including educational services for disability and financial assistance. ${ }^{18}$ Based on this, Japan is a country that emphasizes education as an effort to improve the quality of human resources through equal opportunities for education. Interestingly, education in Japan is based on morality which originates in Japanese culture of knowing one's abilities.

14 Yasumasa, \& Karyono, T. (Translator). (1988). Politics and Moral Education in Japan. In W. K. Cummings, S. Gopinathan, \& Y. Tomoda (Eds.), The Revival of Values Education II Asia And The West (pp. 1-47). Pergamon Press. p.12

15 Ibid.

16 Ibid.

17 Prime Minister and His Cabinet (2006).

18 Ibid. 


\section{Australia}

Unlike Indonesia and Japan, human rights were not specifically regulated in the Commonwealth of Australia Constitution Act. ${ }^{19}$ Australia has a commitment to implement International Instruments related to the Right to Education, especially on Article 26 of the UDHR 1948 and Article 13 of the ICESCR. ${ }^{20}$ State and territorial government are fully responsible for the primary and secondary education. ${ }^{21}$ Government support for education funding is seen in several domestic laws such as The Higher Education Funding Act 1988, The Schools Assistance Act 2008, The Indigenous Education (Target Assistance) Act 2000, The Education Services for Overseas Student Act 2000 and The Disability Discrimination Act 1992. The regulation of education was specifically written in the Australian Education Act 2013 (AEA 2913) which emphasized the four main educational objectives, namely (a) to ensure that the Australian schooling system provides a high quality and highly equitable education for all students by having regard to the following national targets; (b) to acknowledge the matters reffered in to the Preamble; (c) to provide a needs-based funding model for schools applied consistently across all schools which includes: a base mount of funding for every student and additional loadings for students and schools who need extra support and (d) to implement the National Plan for School Improvement. ${ }^{22}$ The government consider the importance of education, and it can see from the government's attention not only to the implementation of education but also high quality education according to the national targets which are supported by high funding budgets.

\subsection{The Right of Education and Criminal Sanctions during the Pandemic Period Indonesia}

The right of education has actually been considered by the government in choosing the strategy to deal with the spread of Covid-19 despite many challenges from media

\footnotetext{
19 Australia., \& Australian Government Solicitor. (2010). Australia's constitution : with overview and notes by the Australian Government Solicitor. Commonwealth of Australia.

${ }^{20}$ Australian Government, \& Attorney-General's Department. (n.d.). Right to Education. Retrieved from https://www.ag.gov.au/RightAndProtections/HumanRight/Human-rightscrutiny/PublicSectorGuidanceSheets/Pages/Righttoeducation.aspx (accessed May 12, 2021)

21 Ibid.

22 Ibid.
} 
and society. Law Number 6 of 2008 on Health Quarantine (UU KK) provided special consideration. The choice of Large-Scale Social Restriction (PSBB) as an emergency response to public health must take into account upon several aspects such as epidemiological considerations, the magnitude of threats, effectiveness, resource support, technical operation, and economic, social, cultural, and security considerations (Article 49 paragraph (2) of the UU KK). Unfortunately, educational considerations were not explicitly stated. However, it did not mean that education was not taken into consideration in determining the PSBB.

Education is basically a right related to the economic, social, and cultural fields as introduced by ICESCR. The right of education is closely related to economic right, social right, and cultural right of a person to be able to develop oneself and one's social environment. The consideration of education appeared in Article 59 number 3 letter (a) of the UU KK, including the scope of the PSBB, which was 'work and study from home'. According to the regulation, face to face or direct formal education activities should be dismissed, but the learning process could take place in a different condition such as Study from home (SFH). It means that during the Public Health Emergency Conditions due to the Covid-19 Pandemic, learning process has met challenges to be conducted remotely through the use of information technology facilities (Article 31 of the National Education System Law). The implementation of distance education must not be arbitrary, but the learning facilities, services, and assessment systems must be guaranteed to meet the national education standards. The Ministry of Education and Culture of the Republic of Indonesia also emphasized that the possibility of distance education is still one of the best options when the end of the Covid-19 pandemic remains uncertain. The imposition of criminal sanctions in Article 67 paragraph (4) of the National Education System Law is emphasized on Education Providers who do not meet the academic administrative requirements of distance education, related to the promised distance education service facilities and quality conformity with national education standards. However, the imposition of criminal sanctions is ultimum remidium since Article 67 paragraph (4) of the National Education System Law emphasized the phrase "fulfilling the requirements" on Article 31 paragraph (3) of the National Education System Law. This has the implication that 
criminal sanctions are applied when administrative sanctions or other sanctions are not complied with by the education provider.

\section{Japan}

After WHO announced the Covid-19 outbreak as a Global Covid-19 Pandemic, Japan adopted a special policy related to education. Prime Minister Shinzo Abe on Thursday, February 27, 2020 asked elementary schools, juniors and high schools nationwide to be closed from Monday through the students' spring break in order to face an "extremely critical period" so that 13 million of students would not be infected. This means that all formal education activities were in a "shutdown" condition so that students stayed at home. This measure was taken by the Japanese government considering the health and safety of children as the main thing. This government's move was based on Law No. 114. The Law Concerning the Prevention of Infections and Medical Care for Patents of Infections 1998 or better known as Infectious $\begin{array}{lllll}\text { Diseases Control Law } & \text { IDCL }\end{array}$ (感染症の予防及び感染症の患者に対する医療に関する法律) categorized Covid-19 as "infectious disease". IDCL 1998 emphasized on the prevention strategy by providing correct information about infections that occur. Therefore, the focus of the regulation was more on the obligation of the parties, which involved the government to spread the right information related to the infection (Article 3), the public to provide the right information regarding infected patients (Article 4) and the obligation of doctors and veterinarians to work together to prevent the spread of infection (Article 5). Nomura divided these infectious diseases into 4 categories, which were (1) hospitalization, (2) restrictions on working, (3) surveillance of "infected individuals" including suspected patients, symptomatic pathogen carriers and asymptomatic pathogen carriers and (4) Infectious Diseases-Type IV which further divided into a group of subject to complete-count survey and a group designated for fixed-point survey. This means that IDCL 1998 only considered education as one of the recipients of information from the government concerning the infection and was required to provide information related to the infection. 
The interesting thing about the way of handling Covid-19 in Japan occurred in the obedience of the citizens in following the directions given by the government. (Machida et al., 2020). Kazuto Suzuki confirmed that the Covid-19 handling strategy by using The Japan Model was based on the character of disciplined citizens. Character education emphasized in Japanese education has paid an important role in handling Covid-19 in Japan. As a result, Japan is among the countries that have succeeded in suppressing the spread of Covid-19 at low levels without having to implement strict policies and sanctions. Important note was taken by Muto, et. al. that the Japanese people placed full trust to the Japanese Government by continuously updating information and Government policies both central and local government through Television News programs and internet news sites (90\%). Furthermore, $64.9 \%$ of Japanese people also seem to support the Social Distancing policy as there is a change in the habits of Japanese society in order to maximize the handling of the spread of Covid-19 including the education sector.

\section{Australia}

During the Covid-19 Pandemic, Australia also implemented a lockdown policy. Since the lockdown was announced on March 20, 2020 by Prime Minister Scott Morrison, various community activities have also experienced a total change, including the education activities. The Government initially provided directions for meetings in an indoor gathering or one area, except for health care arrangements, pharmacies, food shops, schools, workplaces, public and transport. The response to the Covid-19 pandemic also differed from state to state. In the education field, New South Wales had a different emphasis by imposing Social Distancing in schools on March 15, 2020 to suppress the spread of Covid-19. This policy was indirectly emphasized by Brad Hazzard, New South Wales Minister for Health and Medical Research, in the form of banning public meetings attended by more than 500 people. This was based on Section 7 of the Public Health Act 2010 with the threat of imprisonment for 6 months, AUD 11,000 fine, or both, the results were very significant. However, the imposition of criminal sanctions is primum remidium.

\section{Conclusion}

The Covid-19 Pandemic period was truly a challenge for all countries over the world 
to maintain the fulfillment of the right of education over time. Every country that recognized the 1948 UDHR and ratifies ICESCR has the commitment to fulfill the right of education as shown in the State Constitution and Special Laws on education such as Indonesia and Japan or the Special Law on Education by Australia. Indonesia understands that the right of education is the fulfillment of a whole human resource based on religious values and the mastery of science and technology. It appears that the policy of the government of the Republic of Indonesia emphasizes the fulfillment of the rights to education in terms of the availability of online learning. The policy of the Government of the Republic of Indonesia in the field of education during the Covid-19 pandemic put more emphasis on distance learning accompanied by support for internet quota subsidies and the provision of a SPADA platform for learning through the Massive Open Online Source (MOOC) system. In Japan, the right of education viewed as an effort to build a society based on the paradigm of academic freedom which rooted in two main education aspects, moral education (Shushin) and disciplinary education (Shitsuke). Meanwhile, Australia emphasized on the implementation of quality education that must be supported by government's funding in accordance with national targets. Each education paradigm depends on the respective government policies. Indonesia applied PSBB that still allows the implementation of internetbased distance education so that teaching and learning process continues. The imposition of criminal sanctions was emphasized as the last resort (Ultimum remidium). The lockdown policy has been adopted by the Japanese and Australian Governments. The difference was that the Japanese government did not carry out strict policies and gave no sanctions. They relied mainly on the character of the Japanese society who had moral education (Shushin) and disciplinary education (Shitsuke). In contrast, Australia imposed a strict policy on social distancing with imprisonment and/or fines for violators. Based on the comparison of understanding the right of education, each country depends so much on the application of education in the country itself. This also corresponds to the policies adopted during the Covid19 pandemic.

\section{Acknowledgments}

We thank Amelia Elizabeth Meliangan and Jovita Bunga for their research assistance 
and gratefully acknowledge funding provided by the Institute of Research and Community Service (LLPM) University of Surabaya.

\section{References}

\section{Books}

Australia., \& Australian Government Solicitor. (2010). Australia's constitution: with overview and notes by the Australian Government Solicitor. Commonwealth of Australia.

Deparment of Health, A. G. (2020). COVID-19, Australia: Epidemiology Report 3 (Reporting week ending 19:00 AEDT 15 February 2020). Communicable diseases intelligence (2018). Vol. 44 (1). NLM (Medline).

Djalante, R., et.al (2020). Review and analysis of current responses to COVID-19 in Indonesia: Period of January to March 2020. Progress in Disaster Science, Vol. 6 (100091):1-9

Yasumasa, \& Karyono, T. (Translator). (1988). Politics and Moral Education in Japan. In W. K. Cummings, S. Gopinathan, \& Y. Tomoda (Eds.), The Revival of Values Education II Asia and The West (Pergamon Press: 1-47

\section{Journal Article}

Christianto. Hwian. (2020). "Penggunaan Media Internet dalam Pemenuhan Ha katas Pendidikan di Masa Pandemi Covid-19: Perspektif Hak Asasi Manusia dan Hukum Pidana”. Jurnal HAM. Vol.11(2): 239-253 http://dx.doi.org/10.30641/ham.2020.11.239-253

Hamid, A. R. A. H. (2020). "Social responsibility of medical journal: A concern for covid-19 pandemic". Medical Journal of Indonesia. Vol 29 (1): 1-3. https://doi.org/10.13181/mji.ed.204629

Liebig, J., Jurdak, R., Shoghri, A. El, \& Paini, D. (n.d.). “The current state of COVID-19 in Australia: importation and spread.", medRxiv 2020.03.25.20043877: 1-6. https://doi.org/10.1101/2020.03.25.20043877

Machida, M., Nakamura, I., Saito, R., Nakaya, T., Hanibuchi, T., Takamiya, T., Odagiri, Y., Fukushima, N., Kikuchi, H., Kojima, T., Watanabe, H., \& Inoue, S. (2020). "Adoption of personal protective measures by ordinary citizens during the COVID-19 outbreak in Japan". International Journal of Infectious Diseases, Vol. 94(1): 139-144

Muto, K., Yamamoto, I., Nagasu, M., \& Tanaka, M. (2020). Japanese citizens' behavioral changes and. MedRxiv, V.1(1): $1-31$ https://doi.org/10.1101/2020.03.31.20048876 
Nomura, T., Takahashi, H., \& Takeda, Y. (2003). "Changes in Measures against Infectious Diseases in Japan and Proposals for the Future JMAJ, Vol. 46(9): 390400

Sujatmoko, E. (2010). "Hak Warga Negara Dalam Memperoleh Pendidikan". Jurnal Konstitusi, Vol 7 (1): 181-212. https://doi.org/10.31078/jk\%x

Yunus, N. R., \& Rezki, A. (2020). “Kebijakan Pemberlakuan Lock Down Sebagai Antisipasi Penyebaran Corona Virus Covid-19". Salam: Jurnal Sosial Dan Budaya, Vol 7 (3): 227-238. https://doi.org/10.15408/sjsbs.v7i3.15083

\section{Official Web}

AAP reporters. (2020). NSW coronavirus cases spike to 171. Retrieved from: https://7news.com.au/news/health/brace-yourselves-as-nsw-virus-cases-risec-746748 (Accessed May 12, 2021)

ABC Australia. (2020). Cara Australia Tangani Corona: Dari Larang Jabat Tangan Sampai Penahanan Paksa. Retrieved from: https://news.detik.com/abcaustralia/d-4924295/cara-australia-tangani-corona-dari-larang-jabat-tangansampai-penahanan-paksa (Accessed May 12, 2021)

ABC news. (2020). Australia's social distancing rules have been enhanced to slow coronavirus - here's how they work. Retrieved from: https://www.abc.net.au/news/2020-03-20/coronavirus-covid-19-scottmorrison-enhanced-social-distancing/12075532 (Accessed May 12, 2021)

Australian Government, \& Attorney-General's Department. (n.d.). Right to Education. Retrieved from https://www.ag.gov.au/RightAndProtections/HumanRight/Human-rightscrutiny/PublicSectorGuidanceSheets/Pages/Righttoeducation.aspx (accessed May 12, 2021)

BBC News. (2020). Coronavirus: Japan to close all schools to halt spread. Retrieved from: https://www.bbc.com/news/world-asia-51663182. (Accessed May 12, 2021)

CNN Indonesia. (2020). Jepang Berhasil Tekan Corona Tanpa Kebijakan Ketat. Retrievrd https://www.cnnindonesia.com/internasional/20200526075133-113506867/jepang-berhasil-tekan-corona-tanpa-kebijakan-ketat (Accessed May $12,2021)$

Japan Times. (2020). All schools in Japan told to close until April over virus outbreak. Retrieved from: https://www.japantimes.co.jp/news/2020/02/27/national/hokkaidocoronavirus-school/\#.Xs0fYkFzDIV (Accessed May 12, 2021) 
ILO. (2021). Law Concerning the Prevention of Infections and Medical Care for Patients of Infections, Pub. L. No. 114, 1 (1998). Retrieved from: https://www.ilo.org/wcmsp5/groups/public/---ed protect/---protrav/--ilo aids/documents/legaldocument/wcms 113225.pdf (Accessed May 12, 2021)

Manichi Japan. (2020). WHO head deems Japan's battle against coronavirus a "success.". $\quad$ Retrieved from: https://mainichi.jp/english/articles/20200526/p2g/00m/0na/041000c (Accessed May 12, 2021)

Meade, A. (2020). Australian schools stay open amid coronavirus but NSW brings in social distancing. Retrieved from: https://web.archive.org/web/20200316005429/https://www.theguardian.co $\underline{\mathrm{m} / \text { world } / 2020 / \mathrm{mar} / 15}$ (Accessed May 12, 2021)

Pranita, E. (2020). Cara Jepang Lawan Corona, Pemimpin Daerah Punya Kebijakan Sendiri Artikel ini teCara Jepang Lawan Corona, Pemimpin Daerah Punya Kebijakan Sendiri. Retrieved from https://www.kompas.com/sains/read/2020/04/18/110000123/cara-jepanglawan-corona-pemimpin-daerah-punya-kebijakan-sendiri?page=3 (accessed Maym 12, 2021)

Prime Minister of Japan and His Cabinet (2006). Basic Act on Educatioin Japan. Retrieved from: https://www.mext.go.jp/en/policy/education/lawandplan/title01/detail01/13 73798.htm (Accessed May 12, 2021)

Suzuki, K. (2020). COVID-19 strategy: The Japan Model. Retrieved from: https://www.japantimes.co.jp/opinion/2020/04/28/commentary/japancommentary/covid-19-strategy-japan-model/\#.Xs0hSUFzDIV (Accessed May 12, 2021)

United Nations. (1948). Universal Declaration of Human Right. Retrieved from: https://www.ohchr.org/EN/UDHR/Documents/UDHR Translations/eng.pdf (Accessed May 12, 2021)

United Nations. (1966). International Covenant on Economic, Social and Cultural Right. Retrieved from: https://www.ohchr.org/Documents/ProfessionalInterest/cescr.pdf (Accessed May 12, 2021)

World Health Oranization. (2020). Coronavirus disease (COVID-19) pandemic. Retrieved from https://www.who.int/emergencies/diseases/novelcoronavirus2019?gclid=EAIaIQobChMIs9Xjy4nO6QIVCldgCh19EAjmEAAYASAAEgJRZfD Bw E (Accessed May 12, 2021) 